launch stranded, and fifteen canoes, carrying about 150 natives, bore down upon the explorers and commenced a savage attack. The Governor's party opened fire, and the natives promptly beat a retreat. After about half an hour, however, they returned, bringing a pig as a peace offering. Sir William consequently went 180 miles further up the river, and on his return visited the same people again, to find them quite peaceably inclined. The Governor started again on December 26 to explore higher up the Fly River.

THE Survey Department of Burmah has in preparation a new map containing all the latest information derived from the parties sent out by the Department. A preliminary issue omitting all the mountain ranges has recently been published.

Signor G. B. Sacchiero, Italian Consul at Rangoon, sends to the Bollettino of the Italian Geographical Society for December an interesting notice of the savage Chin tribes who occupy the hilly region in the north of Burma about the headwaters of the Irawady. The collective tribal name is variously written Chin, Kyen, Kiyin, Kachin, Kakyen, \&c. ; but they call themselves Sihti, and according to Signor Sacchiero they evidently belong to the Burmese branch of the Mongol stock. In the districts brought under British rule many have already adopted the Burmese dress, and these can with difficulty be distinguished from the Burmese themselves. But the language is more allied to that of the widespread Karen race, and the Karen alphabet composed by the American missionaries in Lower Burma is well suited for expressing the sounds of the Chin idiom. The Chins themselves have no knowledge of letters; nor have they made any progress beyond the rudest state of social culture. They still go nearly naked, and the women on arriving at the age of puberty are tattooed all over the face with a black pigment, being thus disfigured for life, either to prevent the Burmese or the neighbouring tribes from kidnapping them, or else to distinguish them from the women captured by the Chins from the surrounding peoples. They marry early, the bride requiring the consent, not of her parents, but of an elder brother, and the husband promising not to beat her too much, nor to cut her hair if she behaves well. The family yields obedience to the father alone, who recognizes no authority except that of the village chief, this au'hority passing in both cases to the youngest son. The men always carry firearms, and make their own gunpowder, using instead of sulphur a seed called aunglak, first roasted, and then pounded up with charcoal and saltpetre, three parts of the two first to twenty of the last, and mixing the whole with alcohol, or tobacco juice. Both sexes smoke little Indian hookahs, and their favourite drink is khaung, a kind of beer extracted from fermented rice. They live mainly by the chase, and when a boar, stag, or other big game is captured, there are great rejoicings in the village. The quarry is covered from neck to tail in a red cloth, and presented to the "temple," or abode of the nat (spirit); then the "friend of the nat" (priest) pronounces a blessing on the successful hunter, after which all join in the feast, with much tamtaming, shouting, drinking, and dancing through the village. When they descend to the plains, the Chins are Buddhists, but in their villages spirit-worshipper.. Not only every village and every district, but every person has his special nat, mostly a malevolent being who requires to be pacified by propitiatory offerings. The vendetta is a universal institution, feuds being inherited from family to family, from tribe to tribe, and thus leading to constant bloodshed. If a man is drowned, his son reeks vengeance on the water where he perished by piercing it with spears or slashing it about with long knives. Many of the Chins have already tendered their submission to the British authorities, and arrangements are now in progress for extending orderly government over the whole territory.

\section{ON SOME NEEDLESS DIFFICULTIES IN THE STUDY OF NATURAL HISTOR $Y{ }^{1}$}

A LITTLE while ago I read, in the preface to a work on natural history, that the book was "of little value to the scientific reader, but that its various anecdotes, and its minute detail of observation wculd be found useful and entertaining."

What, then, may the "scientific reader" be expected to desire? He must be, in my opinion, a most unreasonable man,

'The Presidential Address to the Royal Microscopical Society, at the annual meeting, on February 12, 189o, by Dr. C. T. Hudson, F.R.S. if he does not thankfully welcome anecdotes of the creatures he wishes to study, when these anecdotes are the result of patien and accurate observation. For it is precisely such information, that is conspicuously absent from many scientific memoirs and monographs; the author generally spending his main space and strength in examining the shape and structure of his animals, and in comparing one with another, but giving the most meagre details of their lives and habits.

Which, then, is the more scientific treatment of a group of animals-that which catalogues, classifies, measures, weighs, counts, and dissects, or that which simply observes and relates? Or, to put it in another way, which is the better thing to doto treat the animal as a dead specimen, or as a living one?

Merely to state the question is to answer it. It is the living animal that is so intensely interesting, and the main use of the indexing, classifying, measuring, and counting is to enable us to recognize it when alive, and to help us to understand its perplexing actions.

But, it may be objected, that because the study of the living animal is the more interesting, it is not necessarily the more scientific; indeed, that the amount of entertainment, which we may get out of the pursuit of natural history, has nothing to do with the question at all; that by science we mean accurate knowledge presented in the most suitable form; that shape, structure, number, weight, comparison are the fundamental notions, with wnich sciences of every lind have to deal ; and that scientific natural history is more properly that which takes cognizance of a creature's size, form, bodily organs, and relation to other creatures, than that which concerns itself with the animal's disposition and habits.

I can fancy that I already hear some of my audience say: "But why set up any antagonism between these two ways of studying a creature? Both are necessary to its thorough comprehension, and our text-books should contain information of both kinds; we should be told how an animal is made, where it ought to be placed among others of the same group, and also how it lives, and what are its ways."

Precisely; that is just what memoirs and text-books ought to do ; but what, too often, they do not. We read much of the animal's organs; we see plates showing that its bristles have been counted, and its muscul ir fibres traced to the last thread; we have the structure of its tissues analyzed to their very elements ; we have long discussions on its title to rank with this group or that; and sometimes even disquisitions on the probable form and habits of some extremely remote, but quite hypothetical ancestor-some "archirotator" (to take an instance from my own subject) who is made to degrade in this way, or to ad. vance in that, or who is credited with one organ, or deprived of another, just as the ever-varying necessities of a desperate hypothesis require :- but of the living creature itself, of the way it lives, of the craft with which it secures its prey or outwits its enemies, of the home that it constructs, of its charming confidence or its diabolical temper, of its curious courtship, its droll tricks, its games of play, its fun and spite, of its perplexing stupidity coupled with actions of almost human sagacity-of all this, this which is the real natural history of the animal, we, too often, hear little or nothing. And the reason is obvious, for in many cases the writer has no such information to give; and, even when he has, he is compelled by fashion to give so much space to that which is considered to be the more scientific portion of his subject, that he has scant room for the more interesting. Neither ought we to be surprised if a writer is " gravelled for the lack of matter," when he comes to speak of an animal's life ; for the study of the lives of a large majority is a difficult one. It requires not only abundant leisure, but superabundant patience, a residence favourably situated for the pursuit, and an equally favourable condition of things at home. The student, the must be ready to adopt the inconvenient hours of the creatures that he watches, and be indifferent to the criticisms of those that watch him. If his enthusiasm will not carry him, without concern, through dark nights, early mornings, vile weather, fatiguing distances, and caustic chaff, the root of the matter is not in him. Besides, he ought to have a natural aptitude for the pursuit, and know how to look for what he wants to see; or if he does not know, to be able to make a shrewd guess : and, above all, when circumstances are not favoprable, to have wit enough to invent some means of making them so. And yet when the place, the man, the animals, and the circumstances all seem to promise a rich harvest of observations, how often it happens that some luckless accident, a snapt twig, a 
lost glass, a hovering kestrel, a sudden gust of wind, a roving dog, or a summer shower, robs the unlucky naturalist of his due; nay, it sometimes happens that, startled by some rare sight, or lost in admiration of it, he himself lets the happy moment slip, and is obliged to be contented with a sketch from memory, when he might have had one from life.

But I have not yet got to the bottom of my budget-the heaviest trouble still remains; and that is, that the result of a day's watching will often go into a few lines, or even into a few words; and so it happens, that the writer of the history of a natural group of animals is too frequently driven to fill up his space with minute analysis of structure, discussions on classification, disputes on the use of obscure organs, or descriptions of trifling varieties; which, exalted to the rank of species, fill his pages with wearisome repetitions; for were he, before he writes his book, to endeavour to make himself acquainted with the habits of all the creatures he describes, his own life-time might be spent in the pursuit.

We will now take a different case, and suppose that many years have been spent in the constant and successful study of the animals themselves; and that the time has come, when the naturalist may write his book, with the hope of treating, with due consideration, the most interesting portion of his subject. $\mathrm{He}$ is now beset with a new class of difficulties, and finds that publishers and scientific fashion alike, combine to drive him into the old groove : for the former limit his space, by naturally demurring to a constantly increasing number of plates and an ever lengthening text ; while the latter insists so strongly on having a complete record of the structure, and points of difference, of every species, however insignificant, that it is hardly possible to do much more than give that record - a mere dry shuck, emptied of nearly all that makes natural history delightful.

And so we come round again to the point that I have already glanced at, viz. "Ought natural history to be delightful?"

Ought it to be delightful! Say, rather, ought it to exist ? What title has the greater part of natural history to any existence but that it charms us? It is true that this study may help-does help many-to worthier conceptions of the unseen, to loftier hopes, to higher praise ; that it gives us broader and sounder notions of the possible relation of animals, not only to one another, but also to ourselves; that it provides us with the material for fascinating speculations on the embryology of our passions and mental powers ; and that it may even serve to suggest theories of the commencement and end of things, of matter, of life, of mind, and of consciousness-grave questions, scarcely to be dealt with successfully by human faculties, but in a condition to be discussed with infinite relish.

When I speak, then, of the pleasure we derive from the study of natural history, I include these graver and higher pleasures in the word.

Here and there, too, no doubt, the knowledge of the powers and habits of animals is materially useful to us; and, indeed, in the case of some of the minuter organisms, may be of terrible importance; but, in that of the large majority of creatures, we might go out of the world unconscious of their existence (as, indeed, very many people do), and yet, unlike the little jackdaw, not be "a penny the worse." For what is a man the better for studying butterflies, unless he is delighted with their beauty, their structure, and their transformations? Why should he learn anything about wasps and ants, unless their ways give him a thrill of pleasure? What can the living plumes of the rock-zoophytes do for us, but 'witch our eyes with their loveliness, or entrance us with the sight of their tiny fleets of medusa-buds, watery ghostlets, flitting away, laden with the fate of future generations?

When, at dusk, we steal into the woods to hear the nightingale, or watch the night-jar, what more do we hope for than to delight our ears with the notes of the one, or our eyes with the flight of the other? When the microscope dazzles us with the sight of a world, whose inhabitants and their doings surpass the wildest flights of nightmare or fairy tale, do we speculate on what possible service this strange creation may render us? Do we give a thought to the ponderous polysyllables that these mites bear in our upper world, or to their formal marshalling into ranks and companies, which are ever being pulled to pieces, to be again re-arranged? No! it is the living creature itself which chains us to the magic tube. For there we see that the dream of worlds peopled with unimagined forms of life-with sentient beings whose ways are a mystery, and whose thoughts we cannot even guess at - is a reality that lies at our very feet; that the air we breathe, the dust that plagues our nostrils, the water we fear to drink, teem with forms more amazing than any with which our fancy has peopled the distant stars; and that the actions of some of the humblest arouse in us the bewildering suspicion, that, even in these invisible specks, there is a faint foreboding of our own dual nature.

If, then, we make some few exceptions, we are entitled to say that the study of natural history depends for its existence on the pleasure that it gives, and the curiosity that it excites and gratifies : and yet, if this be so, see how cruelly we often treat it. Round its fair domain we try to draw a triple rampart of uncouth words, elaborate, yet ever-changing classifications, and exasperatingly minute subdivisions; and we place these diffculties in the path of those whose advantages are the least, those who have neither the vigorous tastes that enable them to clear such obstacles at a bound, nor the homes whose fortunate position enables them to slip round them. For modern town life forces a constantly increasing number of students to take their natural history from books; and too often these are either expensive volumes beyond their reach, or dismal abridgments, which have shrunk, under examination pressure, till they are little else than a stony compound of the newest classification and the oldest woodcuts.

But the happier country lad wanders among fields and hedges, by moor and river, sea-washed cliff and shore, learning zoology as he learnt his native tongue, not in paradigms and rules, but from Mother Nature's own lips. He knows the birds by their flight, and (still rarer accomplishment) by their cries. He has never heard of the (Edicnemus crepitans, the Charadrius pluvialis, or the Squatarola cinerea, but he can find a plover's nest, and has seen the young brown peewits peering at him from behind their protecting clods. He has watched the cunning flycatcher leaving her obvious, and yet invisible young, in a hole in an old wall, while it carried off the pellets that might have betrayed their presence; and has stood so still to see the male redstart, that a field-mouse has curled itself up on his warm foot and gone to sleep. He gathers the delicate buds of the wild rose, happily ignorant of the forty-odd names under which that luckless plant has been smothered; and if, perchance, his last birthday has been made memorable by the gift of a microscope, before long he will be glorying in the transparent beauties of Asplanchna, unaware that he ought to crush his living prize, in order to find out which of some half-dozen equally barbarous names he ought to give it.

The faults, indeed, of scientific names are so glaring, and the subject is altogether so hopeless, that I will not waste either your time or my patience by dilating on it. But, while admitting that distinct creatures must have different names, and very reluctantly admitting that it seems almost impossible to alter the present fashion of giving them, I see no reason why these, as well as the technical names of parts and organs, should not be kept as much as possible in the background, and not suffered to bristle so in every page, that we might almost say with Job, "There are thistles growing instead of wheat, and cockle instead of barley."

We laughed at the droll parody in which the word change was defined as "a perichoretical synechy of pamparallagmatic and porroteroporeumatical differentiations and integrations," yet it would not be a difficult matter to point out sentences, in recent works on our favourite pursuits, that would suggest a similar travesty. No doubt, new notions must often be clothed in new language, and the severer studies of embryology and development require a minute precision of statement that leads to the invention of a multitude of new terms. Moreover, the idea that the meaning of these terms should be contained in the names themselves is excellent; but I cannot say that the result is happyI mightalmost say that it is repulsive; and if we suffer this language to invade the more popular side of natural history, I fear that we shall only write for one another, and that our scientific treatises will run the risk of being looked at only for their plates, and of being then bound up with the Russian and Hungarian memoirs.

The multiplication of species, too, is a crying evil, and the exasperating alterations of their names, in consequence of changing classifications, is another. The former, of course, is mainly due to the difficulty, no doubt a very great one, of determining what shall be a species, and what a variety. How widely experts may differ on this question, Darwin has shown, by pointing out that, excluding several polymorphic genera and many trifling varieties, nearly two hundred British species, which are generally considered varieties, have all been ranked by 
botanists as species; and that one expert has made no fewer than thirty-seven species of one set of forms, which another arranges in three. Besides, even in the cases where successive naturalists have agreed in separating certain forms, and in considering them true species, it happens now and then, as it did to myself, that a chance discovery throws down the barriers, and unites half-a-dozen species into one.

Under these circumstances one would have expected that the tendency would have been to be chary of making new species, and no doubt this is the practice of the more experienced naturalists ; but, among the less experienced, there is a bias in the opposite direction; and all of us, I fear, are liable to this bias when we have found something new ; for, even if it is somewhat insignificant, we are inclined to say with Touchstone, "A poor thing, sir, but mine own!" Now, were this fault mended, much would be avoided that tends to make monographs both expensive and dull; for, though the needs of science require a minute record of the varieties of form, which are sometimes of high importance from their bearing on scientific theories, yet the description of them, as varieties, may often be dismissed in a line or two, when nothing further is set forth than their points of difference; whereas, if these forms are raised to the rank of species, they are treated with all the spacedout dignities of titles, lists of synonyms, specific characters, \&c., $\& c .$, and so take up a great deal of valuable room, weary the student with repetitions, and divert his attention from the typical forms.

But when everything has been done that seems desirable, when names and classincation have been made both simple and stable, and the number of species reduced to a minimum, there will still remain the difficulty that monographs must, from the nature of the case, generally be grave, as well as expensive books of reference, rather than pleasant, readable books, within the reach of the majority. I would suggest then, that, if it be possible, each group of animals should be described not only by an all-embracing monograph, to be kept for reference on the shelves of societres like our own, but by a book that would deal only with a moderate number of typical, or very striking forms that would describe them fully, illustrate them liberally from life, and give an ample account of their lives and habits.

Such a book should give as little of the classification as possible ; it should avoid the use of technical terms, and above all, it should be written with the earnest desire of so interesting the reader in the subject, that he should fling it aside, and rush oft to find the animals themselves. By this means we should not only get that active army of out-of-door observers, which science so greatly needs; but, by bringing the account of each yroup into a reasonable compass, we should enable students of uatural history to get a fair knowledge of many subjects, and so greatly widen their ideas and multiply their pleasures.

For why should we be content to read only one or two chapters of Nature's book? To be interested in many things1 had almost said in everything -and thus to have unfailing agreeable occupation for our leisure hours, is no bad receipt for nappiness. But life is short, and its duties leave scant time for such pursuits; so that to acquire a specialist's knowledge of one subject would often be to exchange the choice things of many subjects for the uninteresting things of one. And how uninter esung many of them are! How is it possible for any human being to take pleasure in being able to distinguish between a aozen similar creatures, that differ from one another in some tritling matter; that have a spike or two more or less on their backs, or a varying number of undulations in the curve of their jaws, or differently set clumps of bristles on their foreheads? Why should we waste our time, and our thoughts, on such matters? The specialist, unfortunately, must know these things, as well as a hundred others equaliy painful to acquire and to retain, and no doubt he has his reward; but that reward is not the ueep delight that is to be found in the varied study of the humbler anınals; of those beings "whom we do but see, and as little know their state, or can describe their interests or their destiny, as we can tell of the inhabitants of the sun and moon; . . creatures who are as much strangers to us, as mysterious, as if they were the fabulous, unearthly beings, more powerful than man, yeı his slaves, which Eastern superstitions have invented."

l'hose, then, who are blest with a love of natural history should never dull their keen appreciation of the wonders and beauties of living things, by studying minute specific differences; or by undertaking the uninteresting office of finding and recording animals, that may indeed be rare, but which differ from those already known in points, whose importance is due solely to arbitrary rules of classification.

This eagerness, to find something new, errs not only in wasting time and thought on matters essentially trivial and dull, but in neglecting things of the greatest interest, which are always and everywhere within reach. Take, for instance, the case of Melicerta ringens. What is more common, what more lovely, than this well-known creature? And yet how much there remains to be found out about it. No one, for example, has ever had the patience to watch the animal from its birth to its death; to find out its ordinary length of life, the time that it takes to reach its full growth, the period that elapses between its full growth and death, or, indeed, if there be such a period. And yet even these are points which are well worth the settling. For, if Melicerta reaches its full growth any considerable time before the termination of its life, it would seem probable that, owing to the constant action of its cilia, it would either raise its tube far atove the level of its head, or else be constantly engaged in the absurd performance of making its pellets and then throwing them away. Who has ever found it in such a condition, or seen it so engaged? yet the uninterrupted action of the pellet cup would turn out the six thousand pellets, which form the largest tube that I am acquainted with, in about eight days, and those of an average tube in less than three; while the animal will live (according to Mr. J. Hood) ${ }^{1}$ nearly three months in a zoophyte trough, and no doubt much longer in its natural condition. It is true that the creature's industry in tube-making is not continuous. It is often shut up inside its tube, when all ciliary action ceases; and, moreover, when expanded, it may be seen at times to allow the formed pellet to drift away, instead of depositing it ; but, allowing for this, there is no little difficulty in understanding how it is that, with so vigorous a piece of mechanism as the pellet-cup, the tube at all ages, except the earliest, so exactly fits the animal. I am aware that it has been stated that the whole of the cilia (including those of the pellet-cup) are under the animal's control, and that their action can be stopped, or even reversed, at pleasure. But this, I think, is an error. Illusory appearances, like those of a turning cog-wheel, may be produced by viewing the ciliary wreath from certain points, and under certain conditions of illumination; and these apparent motions are often reversed, or even stopped, by a slight alteration either in the position of the animal, in the direction of the light, or in the focussing of the objective. When, however, under any circumstances, the cilia themselves are distinctly seen, they are invariably found to be simply moving up and down; now turning sharply towards their base, and now recovering their erect position. Even the undoubtedly real reversal of the revolution of the pellet in its cup, which is constantly taking place, can be easily explained by purely mechanical considerations, and consistently with the continuous up and down motion of the cilia. Moreover, of the actual stoppage of the cilia, in the expanded Rotiferon, I have never seen a single instance. In all cases, on the slightest opening of the corona, the cilia begin to quiver, and they are always in full action, even before the disk is quite expanded; while, should a portion of the coronal disk chance to be torn away, its cilia will continue to beat for some time after its severance : so that there is good reason for believing, that the ciliary action is beyond the animal's control.

It is possible, indeed, that Melicerta may continue to grow (as Mr. Hood says that the Floscules appear to do) as long as it lives; or it may adopt the plan of some species of EEcistes, which, to prevent themselves from being hampered by their ever-growing tubes, quit their original station at the bottom of the tube, and attach themselves to it above, creeping gradually upwards as the tube lengthens. At any rate it would be interesting and instructive to watch the growth of a Melicerta, and the building of its tube, from the animal's birth to its death. An aquarium, in which Melicerta would live healthily and breed freely, could easily be contrived, and a little ingenuity would enable the observer to remove any selected individual to a zoophyte trough and back again, without injury; and his trouble perhaps would be further repaid by such a sight as once delighted my eyes at Clifton, where I picked, from one of the tanks of the Zoological Gardens, some Vallisneria, whose ribbon-like leaves were literally furred with the yellow-brown tubes of

Mr. Hood, of Dundee, has kept in his troughs Melicerta ringens for 79 days, Limnias ceratophylli for 83 days, Cephalosiphon limnias for 89 days : maturity, in 16 days. 
Melicerta. I coiled one of these round the wall of a deep cell, and thus brought into the field of view, at once, more than a hundred living Melicerte of all ages and sizes, and all with their wheels in vigorous action; a display never to be forgotten.

Such a tank, so stocked and managed, would probably enable a patient and ingenious observer to decide several other points, about which we are, at present, in ignorance : to say whether the same individual always lays eggs of the same kind, or whether it may lay now female eggs, now male, now ephippial eggs; and to say what determines the kind of egg that is to be laid ; whether it is the age of the individual, or the supply of food, or temperature, or sexual intercourse that is the potent cause.

It would, too, hardly be possible for the male, to escape the observation of a naturalist, who possessed a tank in which were hundreds of Melicerte: and the male is as yet almost unknown.

Judge Bedwell found in the tubes of the female, in winter, a small Rotiferon resembling the supposed male, that I had seen playing about $M$. tubularia; only the former had a forked foot, and sharp jaws that were at times protruded beyond the coronal disc. Its frequent occurrence in the tubes in various stages of development, and the nonchalance with which the female suffered it to nibble at her ciliary wreath, inclined the observer to conclude, that the animal was the long sought-for male. Unfortunately it was only observed when in motion, so that its internal structure was not made out ; and the matter therefore still rests in some doubt.

No doubt it is a strong argument that the female would probably suffer nothing but a male to take such liberties with her; but it would seem, from the following account, that it is possible for such freedoms to be pushed too far.

Mr. W. Dingwall, of Dundee, was on one occasion watching a male Floscule circling giddily round a female, and constantly annoying her by swimming into her fully expanded coronal cup. Again and again she darted back into her tube, only to find her troublesome wooer blocking up her cup, and sadly interfering with, what to a Floscule is, the very serious business of eating for these animals will oflen eat more than their own bulk in a few hours. It was clear at last that the lady would not tolerate this persistent interference with her dinner; for when-after waiting, rather a longer time than usual, closed up in her tube-she once more expanded, only to find him once more in his old position, she lost all patience, and effectually put an end to his absurdities, by giving one monstrous gulp, and swallowing her lover. It will not surprise you to hear that he did not agree with her, and that after a short time she gave up all hope of digesting her mate, and shot him out into the open again, along with the entire contents of her crop. He fell a shapeless, motionless lump; the two score and ten minutes of a male Rotiferon's life cut short to five; but, strange to say, in a second or two, first one or two cilia gave a flicker, then a dozen; then its body began to unwrinkle and to plump up ; and, at last, the whole corona gave a gay whirl, and the male shot off as vigorous as ever, but no doubt thoroughly cured of its first attachment.

I have taken Melicerta ringens, as an example of what yet remains to be done, even with an animal which is as common in a ditch, as a fly is in a house ; but almost every other Rotifer on would have done equally well, for there is scarcely a single species, whose life-history has been thoroughly worked out.

To me, natural history in many of its branches seems to resemble a series of old, rich mines, that have been just scratched at by our remote ancestors, and then deserted. Our predecessors did their best with such feeble apparatus as they had ; it was not much, perhaps, but it was wonderful that they did it at all with no better appliance; ; and it irks me to think that we, who are equipped in a way which they could not even dream of, should turn our backs on the treasures lying at our feet, and go of prospecting in new spots, contented too often with a poor result, merely because it is from a new quarter.

Besides, the love of novelty is a force too valuable to be wasted on a mere hunt for new species in any one group of animals, especially unimportant ones. It should rather be used to make us acquainted with the more striking forms of many groups. Let us have no fear of the reproach of superficial knowledge; everyone's knowledge is superficial about almost everything; and even in the case of those few who have thoroughly mastered some one subject, their knowledge of that must have been superficial for a great portion of their time. Indeed, the taunt is absurd. I can imagine that a superficial knowledge of law, or surgery, or navigation may bring a man into trouble; but what possible harm can it do himself, or anyone else, that he is content with knowing five Rotifera instead of five hundred? And yet if any naturalist were to study only Floscularia, Philodina, Copeus, Brachionus, and Pedalion, it would give him the greatest possible pleasure, as well as an excellent general notion of the whole class. Let any tyro at the seaside watch the ways and growth of a Plumularia, or of a rosy feather-star, his knowledge of the groups to which they belong could certainly not be dignified even with the term "superficial"-_linear" or "punctiform" would be more appropriate; but the pleasure, that he would derive from such a study, could not be gauged by counting the number of animals that he had examined. It would depend on the man himself; and might, I should readily imagine, far exceed that derived by the study of a hundred times the number of forms in books; especially when such a study had been undertaken, not from a natural delight in it, but from some irrelevant reason, such as to support a theory, to criticize an opponent, to earn a distinction, or to pass an examination.

In truth that knowledge of any group of animals, which would rightly be called superficial when contrasted with the knowledge of an expert, is often sufficient to give us a satisfactory acquaintance with the most interesting creatures in it; to make us familiar with processes of growth and reproduction too marvellous to be imagined by the wildest fancy; and to unfold to us the lives of creatures who, while possessing bodily frames so unlike our own that we are sometimes at a losi to explain the functions of their parts, yet startle us by a display of emotions and mental glimmerings, that raise a score of disquieting questions.

Moreover, there is another excellent reason why we should not confine our attention to one subject; and that is, that even the most ardent naturalist must weary at times of his special pursuit. Variety is the very salt of life; we all crave for it, and in natural history, at all events, we can easily gratify the craving. If we are tired of ponds and ditches, there are the rock-pools of our south-western shores, and the surface of our autumn seas. A root of oar-weed torn at random from a rocky ledge, an old whelk shell from deep water, a rough stone from low-water mark, the rubbish of the dredge, - each and all will afford us delightful amusement. It is wonderful, too, what prizes lurk in humble things, and how often these fall to beginners. The very first time that I tried skimming the sea with a muslin net, I picked a piece of green seaweed off the muslin, intending to throw it away ; but, seeing a little brown spot on it, I dropped the weed (not a square inch) into a bottle of sea-water, instead. At once the brown speck started off and darted wildly round the botile. It was too small to be made out with the naked eye, but by the time I had brought my lens to bear, it had vanished. I hunted all over the bottle, and could see nothing, neither with the lens nor without it. I was half inclined to throw away the water; but, as I was certain that I had seen something in it two minutes before, I corked up the bottle and took it home. When I next looked at it, there was the little brown creature flying about as wildly as ever. I soon made out, now, that I had caught a very tiny cephalopod--something like an octopus-and with a pipette I fished it out, and dropped it into a glass cell. At least dropped the water from the pipette into the cell ; but the animal itself had vanished again; I could not see it either in the bottle or the cell. I was not going to be tricked again; so I pushed the cell under the microscope, and there was my prize ; motionless, but for its panting; and watching me, as it were, up the microscope with its big blue-green eyes. It was almost colourless, and was dotted at wide intervals with very minute black spots, set quincunx fashion-spots absolutely invisible to the sharpest unaided sight.

As I looked it began to blush-to blush faint orange, then deeper orange, then orange-brown; a patch of colour here, another there, now running across one side of the body, now fading away, again to appear on a tentacle ; till at last, as it recovered from its alarm, each black spot began to quiver with rapid expansions and contraction; and then to spread out in ever varying tints, till its wavering outlines had met the expansions of its neighbouring spots; and the little creature, regaining its colour and its courage at the same moment, rushad off once more in a headlong course round the cell.

I was the merest beginner when I saw this, but I had the good luck, knowing nothing whatever about it, and never having given the subject a thought, to see, with my own eyes, how effectually cuttlefishes are protected by their loss of colour, and also to see how the loss takes place. 
No doubt the sea-side of our south-western coasts - I mean its creeks, not "the thundering shores of Bude and Bos"-is a paradise for microscopists; but there is no need that we should travel so far afield. Our inland woods, our lanes and pastures, will yield to us a thousand beauties and wonders. The scarlet pimpernel will show its glorious stamens, the flowers of the wound-wort glow like a costly exotic ; wild mignonette will rival in its fantastic shape the strangest orchid; the humblest gras. will lift a tuft of glistening crystals ; the birch and salad-burnet shake out their crimson tassels; the Jungermanns will display their mimic volcanoes, the mosses unfold the delicate lacework of their dainty urns. But the time would fail me to name one tithe of those sources of wonder and delight that lie all around us; and most of which, as in the case of the Rotifera, contain numberless points on which we are all happily ignorant, and therefore in the best of all possible conditions for deriving endless pleasure and instruction from them. Besides, my time and your patience must, I think, be drawing to a close ; I would then only once more suggest, that we should not only explore for ourselves all these " pastures new" - no matter how imperfectly-but that we should encourage those, who can be our most efficient guides, to indulge us with the main results in the simplest language. Surely one of the most charming subjects, that can interest human beings, admits of being so treated; and there can be no good reason why the Muse of Natural History (for no doubt there is such a Muse) should resemble that curious nymph among the Oribatide, whom $\mathrm{Mr}$. Michell found lying under the moss of an old tree, half smothered in a heap of her cast-off skins, admirable types of successive classifications, and abandoned nomenclature.

Happily, however, books in such matters are of little importance; and names and classifications of still less: both these latter, indeed, are of ephemeral interest; they are the pride of to-day, and the reproach of to-morrow. It is to the living animals themselves that we must turn, fascinated not only with their beauty and their actions, but with the questions which the contemplation of them perpetually provokes, and very rarely answers.

For, in the long procession of the humbler creatures, who can tell where life first develops into consciousness, and why it does so ; where consciousness first stretches beyond the present so as to include the past, and why that happens; or at what point, and why, memory and consciousness themselves are lighted up by the first faint flashes of reason?

We know nothing now of such matters, and probably we never shall know much; but the mere fact that the study of natural history irresistibly draws us to the consideration of these questions, gives to her pleasant features an undoubted dignity, and raises the charming companion of our leisure hours to the rank of an intimate sharer of some of our gravest thoughts.

\section{THE TOTAL ECLIPSE.}

THE U.S.S. Pensacola arrived at Saint Paul de Loanda on December 6, after a voyage of. $5 \mathrm{I}$ days from New York, having made the ports of Horta, Fayal, in the Azores, November 2-3; of Saint Vincent, in the Cape Verdes, November IO-12 ; of Saint George's Parish, Sierra Leone, Novrmber I820 ; and of Flmina, on the Gold Coast, November 26-28.

Immediately on landing at Loanda, it was found that the Rio Quanza steamer, sailing bi-weekly for Muxima, had left two days previously, and that recent washouts along the line of the Caminho de Ferro 'Trans-Africano made it impracticable for the Expedition to reach either Muxima or Cunga early enough to allow sufficient time for monuting and adjusting the instruments for the eclipse.

I therefore at once decided to locate the Expedition at or near Cape Ledo. Mention should be made here of the courteous civilities of His Excellency the Governor of Loanda, for his kindly interest in the Expedition, and the facilities he offered for the prosecution of the various fields of its work.

The Pensacola came to anchor alongside H.M.S. Bramble in the little bay to the north of Cape Ledo, on the afternoon of Sunday, December 8. The Eclipse Station was selected in a very favourable spot close to the shore cliffs, and the sites of the principal instruments were determined before night.

A week or ten days' hard work sufficed for getting a large amount of the apparatus in readiness for the eclipse. I placed Prof. Bigelow in charge of the direct photoheliograph of nearly
40 feet focal length, and detailed $\mathrm{Mr}$. Davis to assist him. Mr. Jacoby was intrusted with the charge of the time-determinations, and longitude and latitude work. The Bramble was at Cape Ledo on a mission like that of the Pensacola, and attendingupon the English Eclipse Expedition in charge of $\mathrm{Mr}$. A. Taylor, F.R.A.S. ; and through the courtesy of her commanding officer, Captain Langdon, R.N., advantage was taken of her run to St. Yaul de Loanda and return, December $14^{-17}$, to make a chronometric determination of the longitude, by comparison with the time at Loanda as determined by Mr. Preston, who was left there by the Expedition for the gravity and magnetic work. Also, on the Bramble's second return to Loanda, on December 23, another comparison was made.

Prof. Abbe was in charge of the meteorological work and of the organization of parties of observers from the ship's company. A large amount of valuable material results from his work.

The mounting and adjustment of the extensive apparatus for the total eclipse, I reserved for myself. A duplex polar axis eleven feet in length had been constructed of six-inch iron tubings, and mounted with great stability. This axis was driven by powerful clock-work of extreme precision, made by Mr. Saegmueller, of Washington. On this single axis was mounted the totality-battery, consisting of 2 Brashear reflecting telescopes of 8 inches diameter, four Clark telescopes of $3 \frac{1}{2}, 5$ $7 \frac{1}{4}$, and 8 inches aperture, the second being rigged with an eyepiece enlarging the sun's image to a diameter of $4 \frac{1}{2}$ inches, the third being used as a high power directing telescope, while the fourth, a photographic doublet with ro inch back lens, loaned by the Harvard College Observatory, was arranged for a series of twelve exposures, two of which were made through an orthochromatizing screen provided by $\mathrm{Mr}$. Carbutt; two six-inch Dallmeyer rapid rectilinear lenses of 24 and 38 inches focus; one Schroeder triple objective, of 6 inches aperture and 22 inches focus; one Gundlach orthoscope of 3 inches aperture and 2 I inches focus ; two flint spectroscopes and one quartz spectroscope loaned by Harvard College Observatory ; a duplex photometer of 75 inches focus also provided by Prof. Pickering, and his reversing layer spectroscope for photographing a spectrum trail for fifteen seconds both before and after second and third contacts; a 5 inch Ross lens of 42 inch focus ; a 4 inch Spencer objective of 36 inch focus, and a 6.4 inch Merz-Clark objective, both rigged with the means of automatic variation of aperture during totality ; and lastly, two duplex cameras provided by Dr. Wright of the Sloane Laboratory of Yale University, for photographic record of the polarization of the corona. In all there were 23 objectives and two mirrors, with their axes adjusted. into parallelism.

With the exception of the Gundlach camera, which was reserved for a special investigation of the extreme outer corona, all this apparatus was operated automatically, by an adaptation, of the pneumatic organ-valve system of Mr. Merritt Gally, of New York. Ex posing shutters were opened and closed, sensitised plates were exchanged for others as soon as exposed, and all the mechanical movements were accomplished with entire precision. Also, by employing an ordinary chronograph in conjunction with the valve system, the exact time of beginning and end of each exposure became a matter of accurate record.

All this apparatus was brought into operation during the period of total eclipse, and over 300 exposures were made in a period of $3 \mathrm{~m}$. Iosec.; but no photographs of the corona were secured, as the sun was completely obscured by clouds. How. ever, the entire success of the pneumatic rnovements is a result of no little value in view of eclipse work in the future.

In addition to this, a silver-on-glass mirror, of 20 inch diameter and 75 feet focal length, by Brashear, lent to the Expedition by Prof. Langley, was so mounted as to throw an image of the corona up the cliff and just linderneath the sun at the time of totality. At the focus a beauliful ro inch image of the sun was formed, and $20 \times 24$ inch plates of the highest sensitiveness were in readiness to record the coronal streamers. This unusual apparatus was also rendered inoperative by clouds.

With the direct photoheliograph, however, very gratifying success was secured. Seventy pictures of the partial phases were made before totality, and forty after. The serious obstacles to the operation of so long a tube were successfully overcome by means of a skeleton mounting, a combined form of an equatorial stand and tripod; and Prof. Bigelow's sand-clock enabled the precise and easy following of the sun. The revolving plate holder, of $\mathbf{2 2}$ inches diameter, actuated automatically by compressed air, in which the principles of the apparatus of the 